\title{
Penerapan Model Numbered Heads Together Berbantu Dakonmatika Pada Kemampuan Pemecahan Masalah Matematika
}

\author{
*Rachma Yunita Sari ${ }^{1}$, Henry Januar Saputra ${ }^{2}$, Mira Azizah ${ }^{3}$ \\ 1,2,3Pendidikan Guru Sekolah Dasar, FIP Universitas PGRI Semarang, Indonesia
}

\author{
A R T I C L E I N F O \\ Article history: \\ Received 10 November \\ 2018 \\ Received in revised form \\ 09 December 2018 \\ Accepted 15 January 2019 \\ Available online 25 \\ February 2019
}

\section{Kata Kunci:}

NHT, dakonmatika,

pemecahan masalah

Keywords:

NHT, dakonmatika, problem

solving skills

\begin{abstract}
A B S T R A K
Rendahnya kemampuan pemecahan masalah matematika menggunakan model pembelajaran konvensional. Penelitian ini bertujuan untuk mengetahui hasil dari penerapan model pembelajaran Numbered Heads Together berbantu media dakonmatika terhadap kemampuan pemecahan masalah matematika di SDN Kembangarum 03 Semarang. Penelitian ini adalah penelitian eksperimen dengan desain penelitian Pre-Experimental Design berbentuk One Group Pretest-Posttest Design. Populasi pada penelitian ini seluruh peserta didik kelas II. Teknik sampling yang digunakan pada penelitian ini adalah sampling jenuh. Sampel yang digunakan pada penelitian ini adalah peserta didik kelas II yang berjumlah 23 peserta didik. Data diperoleh dari hasil pretest dan hasil posttest peserta didik. Rata-rata nilai pretest adalah 58.87, sedangkan rata-rata nilai posttest adalah 78.913. Data yang diperoleh dianalisis menggunakan uji t. Hasil analisis akhir dengan menggunakan uji t, didapatkan harga yaitu 5.524 dan harga yaitu 2.069 atau > maka Ha diterima. Artinya, model Numbered Heads
\end{abstract} Together berbantu media dakonmatika berpengaruh terhadap kemampuan pemecahan masalah matematika pada peserta didik kelas II SDN Kembangarum 03 Semarang.

\begin{abstract}
A B S T R A C T
This study aims to determine the results of the application of Numbered Heads Together learning model assisted by dakonmatics on mathematical problem solving skills in. This research is an experimental research with Pre-Experimental Design research in the form of One Group PretestPosttest Design. The population in this study were all class II students of SD. The sampling technique used in this study is saturated sampling. The sample used in this study was the second grade students of SD, amounting to 23 students. Data obtained from the results of the pretest and posttest results of students. The average value of the pretest is 58.87, while the average posttest value is 78,913. The data obtained were analyzed using the $t$ test. The results of the final analysis using the $t$ test, the price of t_count is 5.524 and the price of t_table is 2.069 or t_count> t_table then Ha is accepted. This means that the Numbered Heads Together model assisted by dakonmatics influences the ability to solve mathematical problems in class II students of SD.
\end{abstract}

\section{Pendahuluan}

Kurikulum 2013 adalah kurikulum yang berlaku dalam Sistem Pendidikan Indonesia. Kurikulum 2013 disiapkan untuk membentuk generasi yang siap menghadapi masa depan. Proses Pembelajaran pada satuan pendidikan diselenggarakan secara interaktif, inspiratif, menyenangkan, menantang, memotivasi peserta didik untuk berpartisipasi aktif, serta memberikan ruang yang cukup bagi prakarsa, kreativitas, dan kemandirian sesuai dengan bakat, minat, dan perkembangan fisik serta psikologis peserta didik. Untuk itu setiap satuan pendidikan melakukan perencanaan pembelajaran, pelaksanaan proses pembelajaran serta penilaian proses pembelajaran untuk meningkatkan efisiensi dan efektivitas

Copyright (C) Universitas Pendidikan Ganesha. All rights reserved. 
ketercapaian kompetensi lulusan(Shafa, 2014). Kurikulum 2013 menitikberatkan pada peningkatan mutu pendidikan dengan menyeimbangkan hardskill dan softskill melalui kemampuan pengetahuan, sikap, dan keterampilan dalam rangka menghadapi tantangan global yang terus berkembang (Mulyasa, 2013). Pernyataan tersebut sesuai dengan tujuan Kurikulum 2013 menurut Permendikbud No. 67 Tahun 2013 tentang Kerangka Dasar dan Struktur Kurikulum Sekolah Dasar/Madrasah Ibtidaiyah yaitu mempersiapkan manusia Indonesia agar memiliki kemampuan hidup sebagai pribadi dan warga negara yang beriman, produktif, kreatif, inovatif, dan afektif serta mampu berkontribusi pada kehidupan bermasyarakat, berbangsa, bernegara, dan peradaban dunia.

Penerapan Higher Order Thinking Skill (HOTS) adalah salah satu cara untuk mencapai tujuan Kurikulum 2013. (Dinni, 2018) Higher Order Thinking Skills merupakan kemampuan untuk memanipulasi, menghubungkan, dan mengubah pengetahuan serta pengalaman yang sudah dimiliki seseorang secara kritis dan kreatif dalam mengambil keputusan untuk menyelesaikan masalah pada situasi yang baru. Higher Order Thinking Skills salah satunya adalah kemampuan pemecahan masalah. Tujuan utama Higher Order Thinking Skills menurut (Saputra, 2016) adalah meningkatkan kemampuan berpikir peserta didik pada level yang lebih tinggi, terutama yang berkaitan dengan kemampuan untuk berpikir secara kritis dalam menerima berbagai jenis informasi, berpikir kreatif dalam memecahkan suatu masalah menggunakan pengetahuan yang dimiliki, serta membuat keputusan dalam situasi-situasi yang kompleks. Menurut Polya (1971), solusi soal pemecahan masalah memuat empat langkah fase penyelesaian, yaitu memahami masalah, merencanakan penyelesaian, menyelesaikan masalah sesuai rencana, dan melakukan pengecekan kembali terhadap semua langkah yang telah dikerjakan.

Pembelajaran matematika adalah suatu proses belajar mengajar yang dibangun oleh guru untuk mengembangkan kreativitas berpikir peserta didik yang dapat meningkatkan kemampuan berpikir peserta didik, serta dapat meningkatkan kemampuan mengkonstruksi pengetahuan baru sebagai upaya meningkatkan penguasaan yang baik terhadap materi matematikanya (Ahmad, 2013). Artinya, pembelajaran matematika bertujuan untuk meningkatkan kemampuan pemecahan masalah peserta didik. Berdasarkan hasil wawancara dengan guru kelas II SDN Kembangarum 03 Semarang pada tanggal 26 September 2018, menunjukkan bahwa peserta didik mengalami kesulitan pada muatan pelajaran matematika khususnya dalam pemecahan masalah matematika. Berdasarkan hasil observasi di kelas II SDN Kembangarum 03 Semarang, permasalahan yang ditemui adalah guru belum menggunakan model pembelajaran yang menarik minat peserta didik. Hal ini menyebabkan peserta didik tidak berperan aktif dalam pembelajaran. Peserta didik hanya mendengarkan penjelasan dari guru dan menulis kembali apa yang ditulis guru di papan tulis sehingga pembelajaran menjadi kurang bermakna. Permasalahan lain yang ditemui adalah guru belum menggunakan alat peraga atau media yang sesuai dengan materi yang menyebabkan pembelajaran kurang menarik sehingga peserta didik merasa bosan serta kesulitan untuk memahami materi.

Guru perlu menerapkan pembelajaran yang menarik minat peserta didik agar peserta didik berperan aktif dalam pembelajaran. Model pembelajaran yang melibatkan peran peserta didik secara aktif salah satunya adalah model pembelajaran kooperatif. Salah satu model kooperatif yaitu model pembelajaran Numbered Heads Together (NHT). Model pembelajaran Numbered Heads Together adalah suatu model pembelajaran berkelompok yang setiap anggotanya bertanggungjawab atas tugas kelompok tersebut. Artinya, tidak ada pemisahan antar peserta didik satu dengan yang lain untuk saling memberi dan menerima antar satu dengan yang lainnya (Niken, Susanto, 2012). (Hamdayana, 2015) NHT merupakan salah satu tipe pembelajaran kooperatif yang menekankan pada struktur khusus yang dirancang untuk mempengaruhi pola interaksi peserta didik dan bertujuan untuk meningkatkan penguasaan akademik. (Hamdayana, 2015) menyatakan bahwa model NHT memiliki beberapa kelebihan, yaitu: a) melatih peserta didik untuk bekerja sama dan menghargai pendapat orang lain, b) melatih peserta didik untuk dapat menjadi tutor sebaya, c) memupuk rasa kebersaman, d) membuat peserta didik terbiasa dengan perbedaan.

Media dakonmatika mengadaptasi dari permainan dakon. Dakon merupakan permainan tradisional yang menggunakan bidang panjang yang menggunakan tujuh cekungan pada masing-masing sisi dan dua cekungan yang lebih besar dibagian tengah ujung kiri dan kanan yang disebut sebagai lumbung (Fad, 2014). Permainan dakon bermanfaat untuk melatih perkembangan motorik, meningkatkan kemampuan kognitif, meningkatkan perkembangan sosial, meningkatkan perkembangan kepribadian, dan memupuk perkembangan emosi (Iswinarti, 2017). Berdasarkan uraian tersebut maka penulis melakukan penelitian tentang "Penerapan Model Numbered Heads Together Berbantu Media Dakonmatika pada Kemampuan Pemecahan Masalah Matematika Kelas II SDN Kembangarum 03 Semarang" 


\section{Metode}

Penelitian ini adalah penelitian eksperimen dengan desain One Group Pretest-Posttest Design. Populasi pada penelitian ini seluruh peserta didik kelas II SDN Kembangarum 03 Semarang. Teknik sampling yang digunakan pada penelitian ini adalah sampling jenuh. Sampel yang digunakan pada penelitian ini adalah peserta didik kelas II SDN Kembangarum 03 Semarang yang berjumlah 23 peserta didik.Data diperoleh dari hasil pretest dan posttest. Sebelum melakukan penelitian, peneliti telah menguji cobakan instrumen soal di kelas II SDN Kalibanteng Kulon 02 Semarang. Instrumen soal uji coba berbentuk uraian yang terdiri dari 10 butir soal. Berdasarkan hasil analisis uji coba instrumen, diperoleh lima soal yang dapat dipergunakan sebagai soal pretest dan posttest. Pengambilan butir soal tersebut mempertimbangkan validitas, reliabilitas, taraf kesukaran, dan daya pembeda soal. Analisis yang digunakan untuk menguji hipotesis adalah uji t(Sugiyono, 2015).

\section{Hasil dan Pembahasan}

Pada Hasil nilai pretest dan posttest dapat dilihat pada tabel 1.

Tabel 1. Data Hasil Pretest dan Posttest

\begin{tabular}{cccccc}
\hline Nilai & Tertinggi & Terendah & Rata-rata & \multicolumn{2}{c}{ Kriteria } \\
& & & & Tuntas & Tidak tuntas \\
\hline Pretest & 82 & 24 & 58,87 & 8 & 15 \\
Posttest & 94 & 58 & 78,913 & 19 & 4 \\
\hline
\end{tabular}

Terdapat perbedaan hasil antara hasil pretest dengan hasil posttest. Hasil pretest menunjukkan nilai tertinggi yaitu 82 dan nilai terendah yaitu 24 dengan rata-rata nilai 58.87. Berdasarkan hasil pretest, terdapat 8 peserta didik mendapat kriteria tuntas dan 15 peserta didik mendapat kriteria tidak tuntas. Hasil posttest menunjukkan nilai tertinggi yaitu 94 dan nilai terendah yaitu 58 dengan rata-rata nilai 78.913. Berdasarkan hasil posttest, terdapat 19 peserta didik mendapat kriteria tuntas dan 4 peserta didik mendapat kriteria tidak tuntas.

Selanjutnya uji normalitas data. Uji normalitas digunakan untuk mengetahui sampel berasal dari populasi berdistribusi normal atau tidak. Perhitungan yang digunakan untuk mengetahui normalitas data menggunakan uji liliefors. Uji normalitas data awal menggunakan nilai pretest dan uji normalitas data akhir menggunakan nilai posttest. Hasil uji normalitas dapat dilihat pada tabel 2.

Tabel 2. Hasil Uji Normalitas

\begin{tabular}{lcccc}
\hline Nilai & N & A & Lo & Ltabel \\
\hline Pretest & 23 & 0.05 & 0.121 & 0.18 \\
Posttest & & & 0.062 & \multirow{2}{*}{. } \\
\hline
\end{tabular}

Berdasarkan tabel 2 diperoleh hasil perhitungan dari hasil pretest didapatkan $L_{0}$ sebesar 0.121 dan dari posttest didapatkan $L_{0}$ sebesar 0.062 dan $L_{\text {tabel }}$ sebesar 0.180 dengan n=23. Jadi, $L_{0}<L_{\text {tabel }}$ maka $H_{0}$ diterima. Artinya, kedua sampel berasal dari data berdistribusi normal.

Uji N-Gain menurut Hake dalam skripsi Murti (2017) digunakan untuk mengetahui adanya peningkatan hasil belajar peserta didik dengan melakukan analisis skor gain ternormalisasi. Hasil perhitungan N-Gain dapat dilihat pada tabel 3.

Tabel 3. Hasil Uji N-Gain

\begin{tabular}{|c|c|c|c|}
\hline Hasil & Pretest & Posttest & \\
\hline Jumlah & 1354 & 1815 & \multirow{2}{*}{0.571} \\
\hline Rata-rata & 58.87 & 78.913 & \\
\hline
\end{tabular}


Berdasarkan tabel 3 diperoleh rata-rata hasil pretest sebesar 58.87 dan rata-rata hasil posttest sebesar 78.913. Berdasarkan data tersebut, diperoleh hasil perhitungan N-Gain sebesar 0.571. Artinya, hasil belajar peserta didik mengalami peningkatan dengan kriteria sedang. Langkah terakhir adalah uji hipotesis menggunakan uji t. hasil uji t dapat dilihat pada tabel 4.

Tabel 4. Hasil Perhitungan Uji T

\begin{tabular}{lrrrrrr}
\hline Hasil & Rata-rata & $\mathrm{N}$ & $\mathrm{Md}$ & $\sum \mathrm{X}^{2} \mathrm{~d}$ & thitung & t table \\
\hline Pretest & 58.87 & \multirow{2}{*}{23} & 20.043 & 6662.957 & 5.524 & 2.069 \\
Posttest & 78.913 & & & & & \\
\hline
\end{tabular}

Berdasarkan Tabel 4 diperoleh rata-rata nilai pretest sebesar 58,87 dan rata-rata nilai posttest sebesar 78,913. Selain itu diperoleh nilai Md sebesar 20,043 dan $\sum X^{2} d$ sebesar 6662,957. Harga $t_{\text {hitung }}$ yaitu 5.524 dan harga $t_{\text {tabel }}$ yaitu 2.069. Artinya, $t_{\text {hitung }}>t_{\text {tabel }}$ maka Ha diterima.

Berdasarkan data yang diperoleh, hasil uji tes awal atau pretest menunjukkan bahwa nilai sebagian peserta didik belum mencapai KKM yang ditentukan yaitu 75 . Nilai rata-rata pretest adalah 58.87 , dari rata-rata nilai tersebut, terdapat 8 peserta didik mendapat kriteria tuntas dan 15 peserta didik mendapat kriteria tidak tuntas. Hasil uji tes akhir atau posttest menunjukkan bahwa nilai rata-rata setelah diberi perlakuan menjadi lebih baik dengan rata-rata nilai 78.913, dari rata-rata nilai tersebut, terdapat 19 peserta didik mendapat kriteria tuntas dan 4 peserta didik mendapat kriteria tidak tuntas. Hal ini menunjukkan bahwa model Numbered Heads Together berbantu media dakonmatika berpengaruh terhadap kemampuan pemecahan masalah matematika kelas II SDN Kembangarum 03 Semarang.

Hasil pretest maupun posttest tersebut telah dilakukan uji normalitas dengan menggunakan uji Lilliefors. Hasil perhitungan uji normalitas awal dengan hasil nilai pretest diperoleh $L_{0}$ sebesar 0.121 dan $L_{\text {tabel }}$ sebesar 0.180 atau $L_{0} \leqslant L_{\text {tabel }}$, sehingga dapat disimpulkan bahwa sampel data pretest berasal dari populasi yang berdistribusi normal. Hasil perhitungan uji normalitas akhir dengan hasil nilai posttest diperoleh $L_{0}$ sebesar 0.062 dan $L_{\text {tabel }}$ sebesar 0.180 atau $L_{0}<L_{\text {tabel }}$, sehingga hasil ini juga menunjukkan bahwa sampel data posttest berasal dari populasi yang berdistribusi normal.

Hasil pretest dan posttest kemudian diuji peningkatan kemampuan pemecahan masalah matematika menggunakan uji N-Gain. Berdasarkan perhitungan uji N-Gain dengan rata-rata nilai pretest sebesar 58,87 dan rata-rata nilai posttest sebesar 78.913, didapatkan hasil sebesar 0.571. Artinya, hasil belajar peserta didik mengalami peningkatan dengan kriteria sedang. Dengan rincian 20 peserta didik mengalami peningkatan dengan kriteria sedang dan tiga peserta didik mengalami peningkatan dengan kriteria tinggi. Berdasarkan perhitungan uji N-Gain tersebut, dapat dikatakan bahwa pembelajaran dengan model Numbered Heads Together berbantu media dakonmatika dapat meningkatkan kemampuan peserta didik kelas II dalam memecahkan masalah matematika materi perkalian dan pembagian bilangan cacah.

Hasil analisis akhir dengan menggunakan uji t, didapatkan harga $t_{\text {hitung }}$ yaitu 5.524 dan harga $t_{\text {tabel }}$ yaitu 2.069 atau $t_{\text {hitung }}>t_{\text {tabel }}$ maka Ha diterima. Artinya, model Numbered Heads Together berbantu media dakonmatika berpengaruh terhadap kemampuan pemecahan masalah matematika pada peserta didik kelas II SDN Kembangarum 03 Semarang.

Menurut Polya dalam (G. dan S. H. Roebyanto, 2017) pemecahan masalah adalah suatu usaha mencari jalan keluar dari suatu kesulitan guna mencapai tujuan yang tidak segera dapat dicapai. Menurut Polya dalam (G. \& S. H. Roebyanto, 2017) terdapat empat langkah dalam penyelesaian masalah, yaitu pemahaman masalah, perencanaan penyelesaian, melaksanakan perencanaan, dan pemeriksaan kembali proses dan hasil. Indikator pemecahan masalah ini diterapkan pada saat peserta didik menjawab soal yang diberikan, yaitu dengan menuliskan diketahui, ditanya, jawab, dan jadi. Indikator pertama yang harus dikuasi oleh peserta didik yaitu memahami masalah. Peserta didik memahami masalah dengan menganalisa data yang diketahui. Penerapan indikator pemahaman masalah adalah peserta didik mampu menulis apa yang diketahui dan apa yang ditanyakan. Kemudian peserta didik menyusun rencana penyelesaian masalah dengan menuliskan rumus yang akan digunakan dan dilanjutkan dengan menyelesaikan masalah sesuai dengan rumus yang telah ditulis. Peserta didik menerapkan indikator perencanaan penyelesaian dan melaksanakan perencanaan pada bagian jawab. Langkah terakhir yaitu melakukan pemeriksaan kembali proses dan hasil. Indikator tersebut diterapkan peserta didik dengan menuliskan kesimpulan jawaban pada bagian jadi. 
Kemampuan pemecahan masalah sangat berpegaruh terhadap hasil belajar peserta didik. (Susanto, 2014) hasil belajar adalah kemampuan yang dimiliki anak setelah melalui kegiatan belajar. Hasil belajar yang diperoleh dalam penelitian ini yaitu kemampuan peserta didik dalam memecahkan masalah matematika, yang awalnya mendapat nilai rata-rata kelas sebesar 58.87, setelah diberi perlakuan menggunakan model Numbered Heads Together berbantu media dakonmatika mendapat nilai rata-rata kelas sebesar 78.913.

Model pembelajaran Numbered Heads Together adalah suatu model pembelajaran berkelompok yang setiap anggotanya bertanggungjawab atas tugas kelompok tersebut. Artinya, tidak ada pemisahan antar peserta didik satu dengan yang lain untuk saling memberi dan menerima antar satu dengan yang lainnya (Ahmad, 2013) Penerapan model Numbered Heads Together di kelas II SDN Kembangarum 03 Semarang ini memberikan kesempatan kepada peserta didik untuk saling mendengarkan pendapat dan saling membantu mencari informasi untuk memecahkan masalah dalam kelompok. Hal tersebut sesuai dengan kelebihan model Numbered Heads Together menurut (Gina Sonia MJ, 2017) yaitu melatih peserta didik untuk bekerja sama dan menghargai pendapat orang lain, melatih peserta didik untuk dapat menjadi tutor sebaya, memupuk rasa kebersaman, dan membuat peserta didik terbiasa dengan perbedaan.

Model pembelajaran Numbered Heads Together mampu mendorong peserta didik untuk bertanggung jawab atas tugas kelompoknya. Dalam penerapannya, peserta didik mendapat kesempatan untuk menemukan dan menerapkan ide-ide mereka sendiri dalam memecahkan masalah, mulai dari memahami masalah, merencanakan penyelesaian, melaksanakan perencanaan, dan memeriksa kembali proses dan hasil. Hal ini didukung teori belajar konstruktivisme dalam (Ahmad, 2013) yang menyatakan bahwa peserta didik harus menemukan sendiri dan mentransformasikan informasi kompleks, mengecek informasi baru dengan aturan-aturan lama, dan merevisinya apakah aturan-aturan itu tidak sesuai lagi. Menurut Slavin dalam (Ahmad, 2013), agar peserta didik benar-benar memahami dan dapat menerapkan pengetahuan, mereka harus memecahkan masalah, menemukan segala sesuatu untuk dirinya, dan berusaha dengan susah payah dengan ide-ide.

Media pembelajaran memiliki peran yang penting sebagai salah satu komponen sistem pembelajaran. Media yang digunakan oleh peneliti yaitu media dakonmatika. Media dakonmatika adalah suatu media yang mengadaptasi dari permainan dakon. Dakon adalah permainan tradisional dengan menggunakan papan yang terdapat cekungan didalamnya serta menggunakan biji dakon. Media dakonmatika dapat membantu peserta didik untuk menghitung perkalian dan pembagian bilangan cacah. Media ini juga dapat membuat peserta didik menjadi lebih aktif dan antusias untuk belajar. Hal tersebut sesuai dengan pendapat Kurniati dalam (Nataliya, 2015) yang menyatakan bahwa permainan tradisional congklak atau dakon merupakan permainan yang menitikberatkan pada kemampuan berhitung. Permainan ini lebih menarik jika diterapkan sebagai media pembelajaran karena peserta didik akan mengikuti pembelajaran dengan aktif.

Berdasarkan analisis data yang dilakukan oleh peneliti, dapat disimpulkan bahwa model Numbered Heads Together berbantu media dakonmatika berpengaruh untuk meningkatkan kemampuan pemecahan masalah matematika kelas II SDN Kembangarum 03 Semarang materi perkalian dan pembagian bilangan cacah.

\section{Simpulan dan Saran}

Berdasarkan hasil penelitian dan pembahasan, dapat disimpulkan bahwa model Numbered Heads Together berbantu media dakonmatika berpengaruh terhadap kemampuan pemecahan masalah matematika kelas II SDN Kembangarum 03 Semarang pada materi perkalian dan pembagian bilangan cacah. Hal ini dibuktikan dengan perhitungan uji t, dengan rata-rata nilai pretest sebesar 58,87 dan ratarata nilai posttest sebesar 78.913, didapatkan harga yaitu 5.524 dan harga yaitu 2.069 atau > maka Ha diterima. Artinya, model Numbered Heads Together berbantu media dakonmatika berpengaruh terhadap kemampuan pemecahan masalah matematika pada peserta didik kelas II SDN Kembangarum 03 Semarang.

Berdasarkan hasil penelitian mengenai penerapan model Numbered Heads Together berbantu media dakonmatika, peneliti memberikan saran yaitu: guru dapat mengembangkan kreatifitas dalam mengajar dengan menerapkan model Numbered Heads Together karena model tersebut dapat membuat peserta didik aktif serta bersemangat dalam pembelajaran, guru dapat menggunakan media dakonmatika untuk membantu peserta didik memahami materi perkalian dan pembagian bilangan cacah, sehingga tujuan pembelajaran tercapai, peneliti selanjutnya dapat menggembangkan model Numbered Heads Together untuk meningkatkan hasil belajar peserta didik khususnya dalam pembelajaran matematika. 


\section{Daftar Rujukan}

Ahmad, S. (2013). Teori Belajar dan Pembelajaran di Sekolah Dasar. Jakarta: Kencana Prenada Media Group.

Dinni, H. N. (2018). HOTS ( High Order Thinking Skills ) dan Kaitannya dengan Kemampuan Literasi Matematika. Prisma, 1, 170-176.

Fad, A. (2014). Kumpulan Permainan Anak Tradisional Indonesia. Jakarta: Penebar Swadaya Grup.

Gina Sonia MJ, D. (2017). Penerapan Model Numbered Head Together (Nht) Dalam Pembelajaran IPS Di Sekolah Dasar untuk Meningkatkan Keterampilan Sosial Siswa Kelas IV SDN Dawuan Timur Ii. METODIK DIDAKTIF, Jurnal Pendidikan Ke-SD-Aan, 1(1), 26-32. https://doi.org/https://doi.org/10.17509/md.v13i1.7690

Hamdayana, J. (2015). Model dan Metode Pembelajaran Kreatifdan Berkarakter. Bogor: Ghalia Indonesia. Iswinarti. (2017). Permainan Tradisional: Prosedur dan Analisis Manfaat Psikologis. Malang: UMM Press. Mulyasa, E. (2013). Pengembangan Implementasi Kurikulum 2013. Bandung: PT Remaja Rosdakarya.

Nataliya, P. (2015). Efektivitas Penggunaan Media Pembelajaran Permainan Tradisional Congklak Untuk Meningkatkan Kemampuan Berhitung Pada Siswa Sekolah Dasar. Jurnal Ilmiah Psikologi Terapan, 3(2), 343-358.

Niken, Susanto, T. B. S. (2012). Penerapan pembelajaran matematika melalui model pembelajaran reciprocal dalam mengatasi kesalahan siswa menyelesaikan soal matematika kelas IX SMP N 1 pakusari pokok bahasan statistika semester ganjil tahun ajaran 2012/2013. Kadikma, 3(3), 95108.

Polya, G. (1971). How to Solve It: A New Aspect of Mathematics Method. New Jersey: Princeton University Press.

Roebyanto, G. \& S. H. (2017). Pemecahan Masalah Matematika Untuk PGSD. Bandung: PT Remaja Rosdakarya.

Roebyanto, G. dan S. H. (2017). Pemecahan Masalah Matematika Untuk PGSD. Bandung: PT Remaja Rosdakarya.

Saputra, H. (2016). Pengembangan Mutu Pendidikan Menuju Era Global: Penguatan Mutu Pembelajaran dengan Penerapan HOTS (High Order Thinking Skills). Bandung: SMILE's Publishing.

Shafa. (2014). Karakteristik proses pembelajaran kurikulum 2013. Dinamika Ilmu, 14(1), 81-96.

Sugiyono. (2015). Metode Penelitian Pendidikan (Pendekatan Kuantitatif, kualitatif, dan R\&D). Bandung: Alfabeta.

Susanto, A. (2014). Pengembangan Pembelajaran IPS di Sekolah Dasar. Jakarta: Prenamedia Group. 